\title{
Synthesis of 4-amino-5-(3-chlorobenzo[b]thien-2-yl)-3-mercapto- 1,2,4-triazolo[3,4-b][1,3,4]thiadiazoles and triazolo[3,4,b][1,3,4]thiadiazines under classical and microwave conditions
}

\author{
E. S. H. El Ashry* ${ }^{\ddagger}$, A. A. Kassem, H. Abdel-Hamid, F. F. Louis, Sh. A. N. Khattab, \\ and M. R. Aouad ${ }^{\S}$
}

Chemistry Department, Faculty of Science, Alexandria University, Alexandria, Egypt

E-mail: Eelashry60@hotmail.com

\begin{abstract}
Conventional heating and microwave (MW) irradiation of 3-chloro-2chlorocarbonylbenzo $[b]$ thiophene (1) with hydrazine hydrate afforded the corresponding hydrazide 2. Potassium dithiocarbazate 3 was cyclized with hydrazine to afford 4-amino-5-(3chlorobenzo[b]thien-2-yl)-3-mercapto-1,2,4-triazole (4). Treatment of 4 with formic acid afforded the $\mathrm{N}$-formyl derivative $\mathbf{5}$ and not the cyclized product $\mathbf{6}$, but with acetic anhydride afforded the triazolothiadiazole 8. Reaction of $\mathbf{4}$ with carbon disulfide in pyridine afforded 3-(3chlorobenzo[b]thien-2-yl)-1,2,4-triazolo[3,4-b][1,3,4]thiadiazol-6(5H)thione (9) which was alternatively obtained by fusion of 4 with thiourea. Fusion of 4 with urea gave 6-amino-3-(3chlorobenzo[b]thien-2-yl)-1,2,4-triazolo $\quad[3,4-b][1,3,4]$ thiadiazol-6(5H)one (11). The 3-(3chlorobenzo[b]thien-2-yl)-5H-1,2,4-triazolo[3,4-b][1,3,4]thiadiazino[5,6-b]quinoxaline (12) was synthesized by reaction of 4 with 2,3-dichloroquinoxaline. Simultaneous deamination and dethiolation of $\mathbf{4}$ gave 14. Carboxymethylation of $\mathbf{4}$ afforded 15 and not the cyclized compound 16. Carbethoxymethylation of $\mathbf{4}$ in presence of triethylamine afforded the thioalkylated product 17 and in presence of sodium ethoxide gave two 1,2,4-triazolo[1,3,4]thiadiazine derivatives 16 and 18. Better yields and shorter reaction times were achieved using MW.
\end{abstract}

Keywords: Benzo[b]thiophene, 1,2,4-triazole, 1,2,4-triazolo[3,4-b][1,3,4]thiadiazines, 1,2,4triazolo[3,4-b][1,3,4]thiadiazoles, microwave irradiation

\footnotetext{
${ }^{\ddagger}$ Present address: International Center for Chemical Sciences, HEJ Research Institute, University of Karachi, Karachi, Pakistan

${ }^{\S}$ On leave from the Ministry of High Education and Scientific Research, Algeria
} 


\section{Introduction}

Compounds bearing the 1,2,4-triazole ring are well known as powerful antimicrobial, ${ }^{1}$ anticonvulsant, ${ }^{2}$ antidepressant, ${ }^{3}$ antihypertensive, ${ }^{4}$ antitumorial ${ }^{5}$ and analgesic ${ }^{6}$ agents. Moreover, some 1,2,4-triazoles and 1,2,4-triazolo[3,4-b][1,3,4]thiadiazines derived from 4amino-3-mercapto-1,2,4-triazoles are associated with diverse pharmacological activities. ${ }^{7-11}$

On the other hand, benzo[b]thiophene are of current interest due to their wide spectrum of pharmacological properties as antiallergic, ${ }^{12}$ antiinflammatory, analgesic ${ }^{13,14}$ and ocular hypotensive activities. ${ }^{15} \mathrm{~A}$ drug based on the benzo[b]thiophene ring is Raloxifene, approved by the U. S. Food and Drug Administration for the prevention and treatment of osteoporosis associated with woman postmenopansal. ${ }^{16}$

Continuing our efforts directed toward the synthesis of new heterocyclic compounds with anticipated biological activities, we have investigated a green chemistry approach for the synthesis of heterocycles combining the benzothiophene and triazolothiadiazole or triazolothiadiazine rings. Much attention has been recently directed in our laboratory to use microwave (MW) in organic synthesis, ${ }^{17-27}$ as a result of its extensive popularity as a powerful tool for rapid and efficient synthesis of a variety of organic compounds. It has not only been used to dramatically accelerate organic reactions, but also to improve both the yields and selectivity ${ }^{28-}$ 30

\section{Results and Discussion}

Microwave irradiations were done on reaction mixtures, placed in a closed Teflon vessel, by using a domestic microwave. Thus 3-chloro-2-chlorocarbonylbenzo[b]thiophene (1) was mixed with hydrazine hydrate and then were irradiated for $1.5 \mathrm{~min}$ to give 3-chloro-2hydrazinocarbonylbenzo[b]thiophene (2) in $98 \%$ yield; conventional heating required $1 \mathrm{~h}$ to give 2 in $80 \%$ yield. ${ }^{31}$ Condensation of $\mathbf{2}$ with carbon disulfide in ethanol containing potassium hydroxide required $4 \mathrm{~min}$, under $\mathrm{MW}$, to give the corresponding potassium dithiocarbazate 3 , whereas the conventional method required $16 \mathrm{~h}$. Ring closure of 3 with an excess of hydrazine hydrate afforded 4-amino-5-(3-chlorobenzo[b]thien-2-yl)-3-mercapto-1,2,4-triazole (4) in $72 \%$ yield upon heating for $4 \mathrm{~h}$, while the reaction time was reduced to 2 min with an improvement of the isolated yield (86\%) upon irradiation with MW (Scheme 1). Its ${ }^{1} \mathrm{H}$ NMR spectrum showed the two characteristic singlets of the $\mathrm{NH}_{2}$ and $\mathrm{SH}$ protons at $\delta 5.84$ and 14.20 , respectively. 


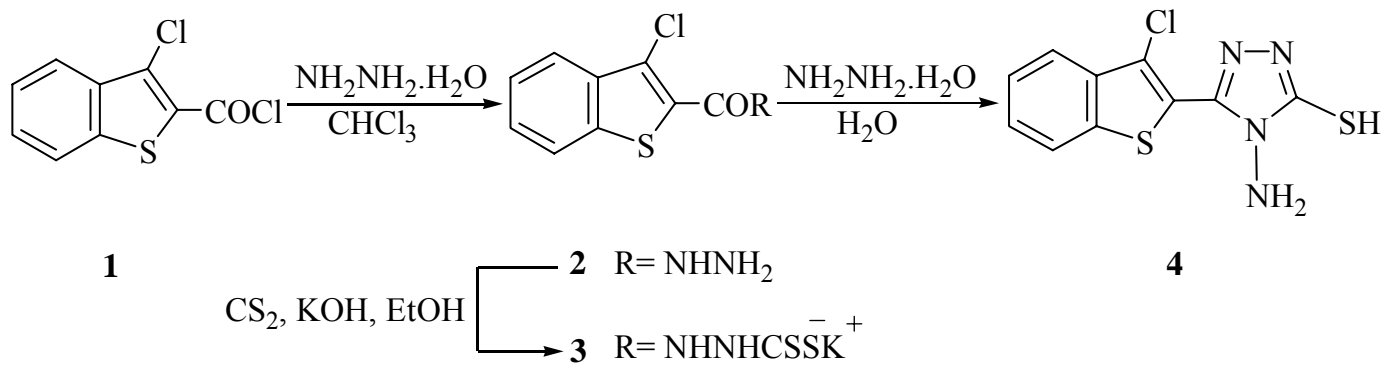

\section{Scheme 1}

The functionalities in 4-amino-3-mecapto-5-substituted-1,2,4-triazoles made them valuable key precursors for the formation of fused heterocyclic compounds containing 1,2,4-triazolo[3,4$b][1,3,4]$ thiadiazoles and $[1,3,4]$ thiadiazines. ${ }^{32-34}$ Thus, treatment of $\mathbf{4}$ with formic acid under reflux for $20 \mathrm{~h}$ afforded the $\mathrm{N}$-formyl derivative 5 in $83 \%$ yield (Scheme 2). The same product 5 was also obtained in $92 \%$ yield, by subjecting the reaction mixture to MW for $3 \mathrm{~min}$; the cyclized product 6 could not be detected. The IR spectrum of 4 showed absorption band at 1690 $\mathrm{cm}^{-1}$ for the carbonyl amide group. Its ${ }^{1} \mathrm{H}$ NMR spectrum in DMSO- $d_{6}$ solution showed a characteristic signal for the SH-proton at $\delta_{\mathrm{H}} 14.58$ of one proton intensity indicating the preference of the thiol over the thione form. It showed the presence of two pairs of singlets for $\mathrm{H}-\mathrm{CONH}$ protons at $\delta 8.33$ and 8.38 in a ratio (1:6), and at $\delta 11.09$ and 11.79 , with the same ratio (1:6). This pairing of signals might be attributed to the different steric arrangement of amidic functionality in the geometric forms (A) and (B) with a predominance of the isomer (A) due to the possibility of hydrogen bonding between $\mathrm{N}-\mathrm{H}$ and thiophene sulfur atom which could be more stronger than that in $\mathrm{B}$. Attempted cyclization of 5 with $\mathrm{H}_{2} \mathrm{SO}_{4}$ to the respective triazolothiadiazole 6 using a reported procedure ${ }^{35}$ was unsuccessful under both conventional and MW conditions. Reaction of 4 with boiling acetic anhydride for $18 \mathrm{~h}$ caused a ring closure to form the thiadiazole ring of $\mathbf{8}$ in $80 \%$ yield, whereas $\mathbf{8}$ was obtained in $91 \%$ within 3 min under MW, via the possible formation of intermediate 7 which could be isolated in other analogues. ${ }^{36}$ The IR and ${ }^{1} \mathrm{H}$ NMR spectra of $\mathbf{8}$ confirmed the success of the cyclization by the disappearance of the signals corresponding to the $\mathrm{SH}$ and $\mathrm{NH}_{2}$ protons and appearance of a singlet at $\delta 2.78$ assigned to the methyl protons.

Heating compound 4 under reflux for $8 \mathrm{~h}$ with carbon disulfide in pyridine furnished 3-(3chlorobenzo[b]thien-2-yl)-1,2,4-triazolo[3,4-b][1,3,4]thiadiazol-6(5H)thione (9) in 70\% yield (Scheme 2); 4 minutes were required under MW to afford 9 in $81 \%$ yield. Alternatively, compound 9 was obtained in moderate yield when a homogenous mixture of $\mathbf{4}$ and thiourea was fused for $3 \mathrm{~h}$ at $180-190{ }^{\circ} \mathrm{C}$. Its ${ }^{1} \mathrm{H}$ NMR spectrum showed a singlet at $\delta_{\mathrm{H}} 9.40$ due to the $\mathrm{NH}$ group.

Fusion of 4 with urea gave 3-(3-chlorobenzo[b]thien-2-yl)-1,2,4-triazolo[3,4b] $[1,3,4]$ thiadiazol-6(5H)one $(\mathbf{1 0})$. 


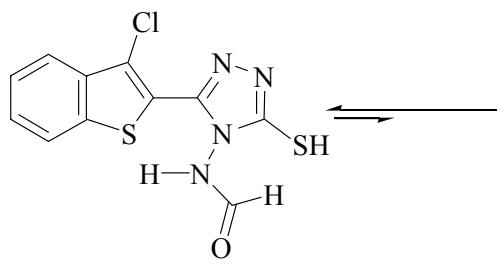

$5 \mathrm{~A}$
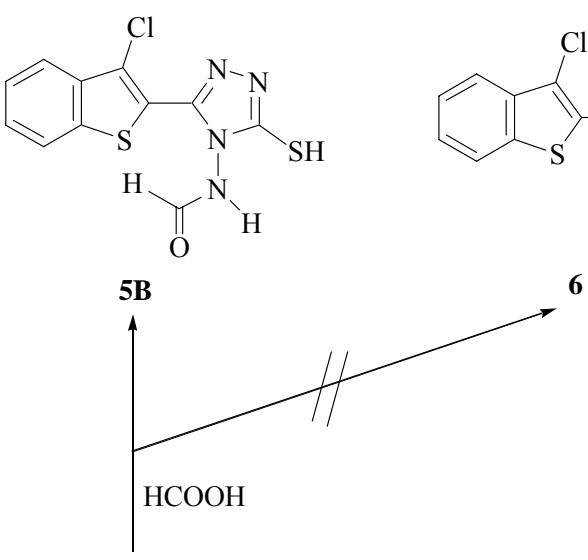
6

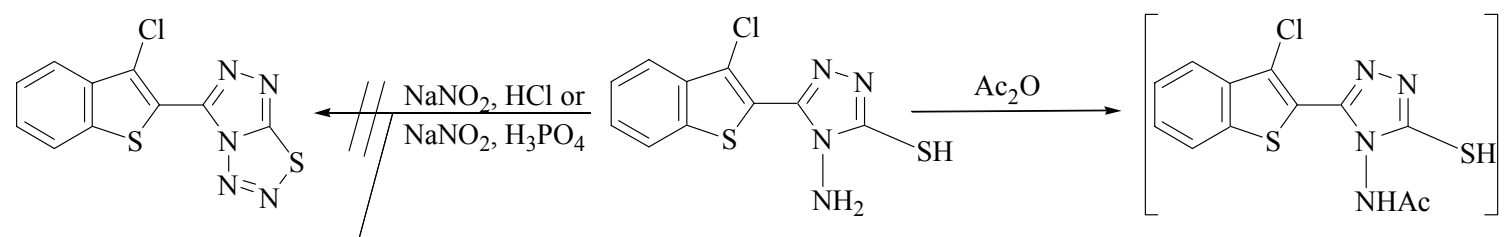<smiles>Clc1c(-c2nnc[nH]2)sc2ccccc12</smiles>

4

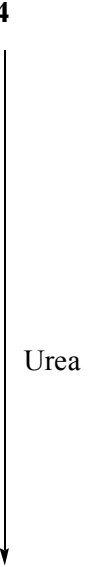

14<smiles>Clc1c(-c2nnc3n2Nc2nc4ccccc4nc2S3)sc2ccccc12</smiles><smiles>Clc1c(-c2nnc3scnn23)sc2ccccc12</smiles>
NHAc
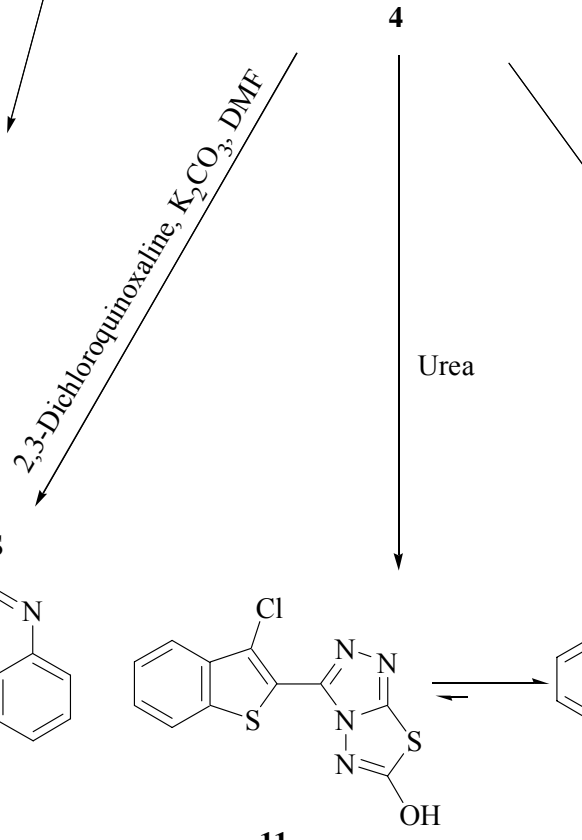

11
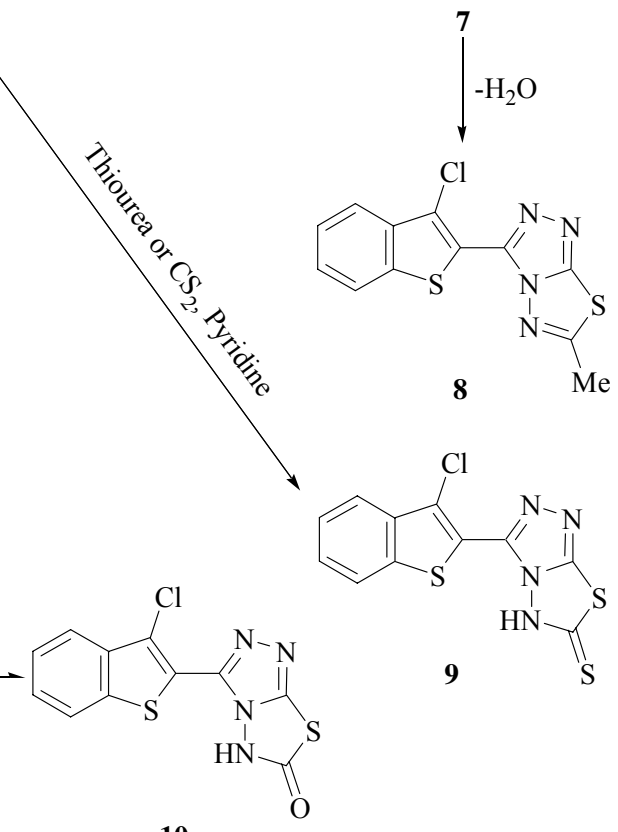

\section{Scheme 2}

Reaction of 4 with 2,3-dichloroquinoxaline in presence of $\mathrm{K}_{2} \mathrm{CO}_{3}$ in DMF afforded 3-(3chlorobenzo[b]thien-2-yl)-5H-1,2,4-triazolo[3,4-b][1,3,4]thiadiazino[5,6- $b]$ quinoxaline under both conventional heating $(2 \mathrm{~h})$ or MW $(1.5 \mathrm{~min})$ in 82 and $94 \%$ yield, respectively. Its ${ }^{1} \mathrm{H}$ NMR spectrum showed the presence of a singlet at $\delta_{\mathrm{H}} 11.85$ corresponding to the $\mathrm{NH}$ proton.

Treatment of 4 with sodium nitrite in either orthophosphoric acid or hydrochloric acid at $0{ }^{\circ} \mathrm{C}$ or under MW for 2 min resulted, after neutralization with sodium hydroxide, in a deamination and dethiolation processes with the formation of 3-(3-chlorobenzo[b]thien-2-yl)-4H-1,2,4- 
triazole (14) rather than 1,2,4-triazolo[4,3-d][1,2,3,4]thiatriazole (13). This result indicated the generality of this reaction, which we have recently reported. ${ }^{24}$

The structure of 14 was confirmed from its ${ }^{1} \mathrm{H}$ NMR spectrum, which showed a singlet at $\delta_{\mathrm{H}}$ 8.69 for the triazole $\mathrm{H}-3$ in addition to the singlet at $\delta_{\mathrm{H}} 13.94 \mathrm{ppm}$ for the NH proton of the triazole ring.

Carboxymethylation of $\mathbf{4}$ with chloroacetic acid in $\mathrm{H}_{2} \mathrm{O}$ in presence of $\mathrm{KOH}$ as basic catalyst under conventional heating for $6 \mathrm{hr}$ or $\mathrm{MW}$ for $2.5 \mathrm{~min}$ afforded 4-amino-5-(3chlorobenzo[b]thien-2-yl)-3-mercaptoacetic acid-1,2,4-triazole (15) in $80 \%$ and $90 \%$, respectively (Scheme 3). The structures of the products resulting from the carboxymethylation of 4-amino-5-mercapto-1,2,4-triazoles were found in literature ${ }^{37,38}$ to be either from uncyclized such as $\mathbf{1 5}$ or cyclized such as $\mathbf{1 6}$. The uncyclized nature of $\mathbf{1 5}$ was confirmed from its elemental analysis which was consistent with the molecular formula $\mathrm{C}_{12} \mathrm{H}_{9} \mathrm{ClN}_{4} \mathrm{O}_{2} \mathrm{~S}_{2}$, and the existence of two singlets in the ${ }^{1} \mathrm{H}$ NMR spectrum at $\delta_{\mathrm{H}} 6.23$ and 12.38 for the $\mathrm{NH}_{2}$ and $\mathrm{COOH}$ protons, respectively which ruled out the existence of the cyclized compound $\mathbf{1 6 .}$

On the other hand, carbethoxymethylation of 4 with ethyl chloroacetate in presence of triethylamine as catalyst in ethanol either under conventional heating for $2 \mathrm{~h}$ or under MW for 1.5 min resulted in the S-alkylation affording the uncyclized product $\mathbf{1 7}$ rather than $\mathbf{1 6}$ or 18. However, using aqueous potassium hydroxide in stead of triethylamine caused the elimination of a molecule of ethanol whereby the cyclized product 1,2,4-triazolo[1,3,4]thiadiazine derivative 16 was obtained. Its IR spectrum showed the absence of ester carbonyl absorption at $1724 \mathrm{~cm}^{-1}$, characteristic for 17, and showed instead amidic carbonyl absorption at $1670 \mathrm{~cm}^{-1}$. The ${ }^{1} \mathrm{H} \mathrm{NMR}$ spectrum of 16 revealed the amidic proton of $\mathrm{CONH}$ at $\delta_{\mathrm{H}} 8.90$, whereas the $\mathrm{NH}_{2}$ protons in 17 appeared at $\delta_{\mathrm{H}} 5.24$.

When the above reaction was carried out using sodium ethoxide as catalyst either by conventional heating or MW, the two 1,2,4-triazolo[1,3,4]thiadiazine derivatives 16 and 18 were obtained as a result of elimination of a molecule of water or ethanol, respectively. 

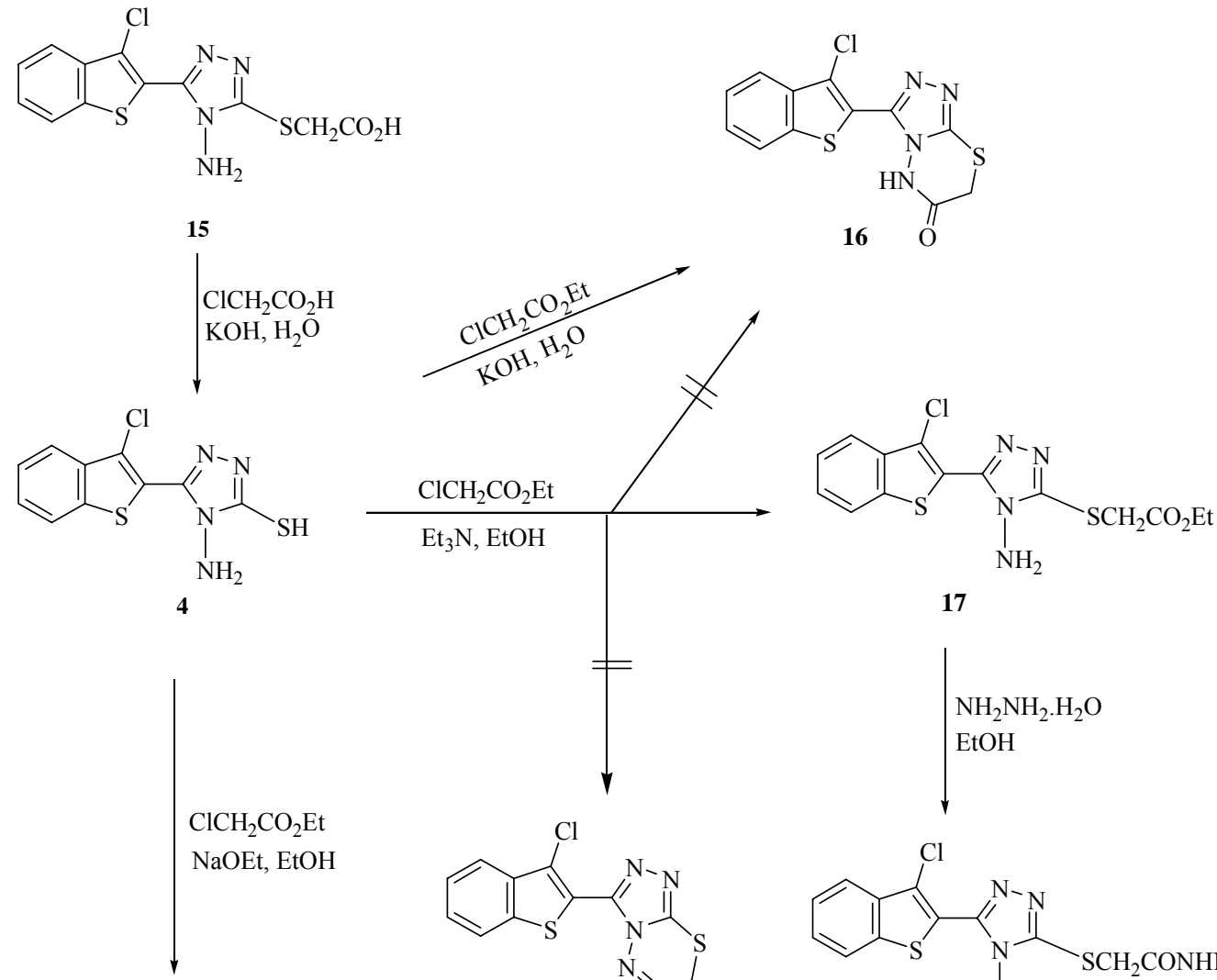

$16+18$
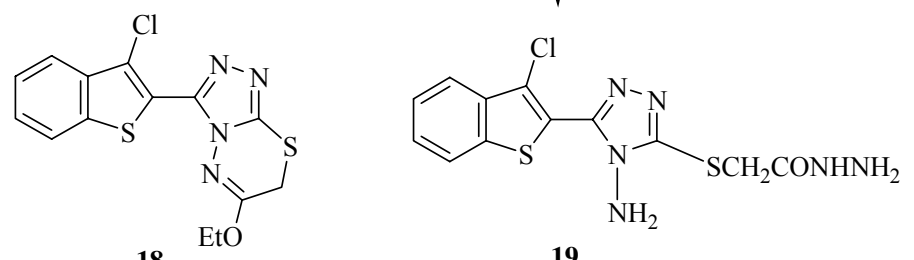

19

\section{Scheme 3}

Nucleophilic attack of hydrazine on the carbonyl-ester of $\mathbf{1 7}$ has been carried out by using MW for 2 min to afford the corresponding acid hydrazide 19 in $92 \%$ yield; conventional heating required 6 h to give $81 \%$.

No reaction was observed under several attempts to react compound 4 with benzoin or dimedone in presence of different bases such as $\mathrm{NaOH}, \mathrm{NaOEt}, \mathrm{NaOAc}$ or $\mathrm{NaH}$ either under conventional heating or MW. Surprisingly, when the reactions were carried out in presence of $\mathrm{NaH}$ in DMF either by heating or under MW, an unexpected product was obtained which was found to be identical to that obtained from boiling 4 in DMF only. The ${ }^{1} \mathrm{H}$ NMR of this unexpected product confirmed the structure to be 3-(3-chlorobenzo[b]thien-2-yl)-6-(N,Ndimethylamino)-1,2,4-triazolo[3,4-b][1,3,4]thiadiaz- ole (21), a result of possible formation of 20 and subsequent dehydrogenation (Scheme 4). The ${ }^{1} \mathrm{H}$ NMR spectrum of 21 indicated the presence of two methyl groups and the absence of a signal corresponding to the formyl proton. 


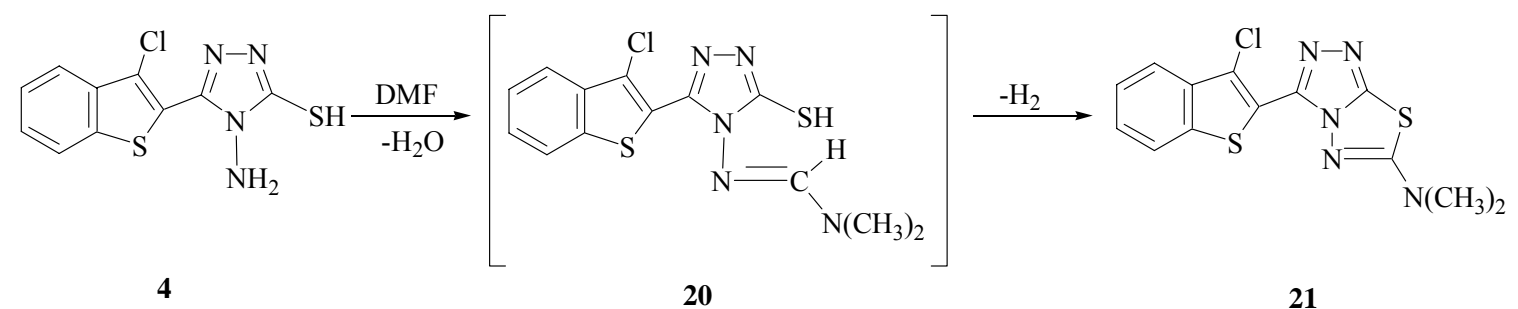

\section{Scheme 4}

In conclusion 4-Amino-5-(3-chlorobenzo[b]thien-2-yl)-3-mercapto-1,2,4-triazole (4) has proved to be a versatile precursor for the synthesis of various heterocyclic compounds possessing the benzothienyl ring linked to fused or functionalized triazole rings. The microwave technique has continued to add further improvements on the performance of reactions to provide products more efficiently in higher yields and in less reaction times (Table 1).

Table 1. Comparative data of conventional (A) and MW (B) methods for the synthesis of compounds 2-21

\begin{tabular}{lllll}
\hline \multirow{2}{*}{ Compound No } & \multicolumn{2}{l}{ Conventional method (A) } & \multicolumn{2}{l}{ Microwave Method (B) } \\
& Time (hr) & Yield (\%) & Time (min) & Yield (\%) \\
\hline $\mathbf{2}$ & 1 & 81 & 1.5 & 98 \\
$\mathbf{4}$ & 4 & 72 & 2.0 & 86 \\
$\mathbf{5}$ & 20 & 83 & 3.0 & 92 \\
$\mathbf{8}$ & 18 & 80 & 3.0 & 91 \\
$\mathbf{9 *}$ & 3 & 54 & - & - \\
$\mathbf{9}$ & 8 & 70 & 4.0 & 81 \\
$\mathbf{1 1}$ & 3 & 60 & - & - \\
$\mathbf{1 2}$ & 2 & 82 & 1.5 & 84 \\
$\mathbf{1 4}$ & 24 & 64 & 2.0 & 76 \\
$\mathbf{1 4} * *$ & 24 & 61 & 2.0 & 73 \\
$\mathbf{1 5}$ & 6 & 80 & 2.5 & 90 \\
$\mathbf{1 6}$ & 8 & 78 & 3.0 & 90 \\
$\mathbf{1 7}$ & 2 & 84 & 1.5 & 96 \\
$\mathbf{1 6}$ & 10 & 81 & 4.0 & 92 \\
$\mathbf{1 9}$ & 6 & 81 & 2.0 & 92 \\
$\mathbf{2 1}$ & 20 & 73 & 6.0 & 84 \\
\hline
\end{tabular}

* by fusion; ** using $\mathrm{H}_{3} \mathrm{PO}_{4}$ 


\section{Experimental Section}

General Procedures. Melting points were determined with a Melt-temp apparatus and are uncorrected. Irradiation was done in a domestic microwave oven EM-230M (1200 Watt output power under defrost temperature). The reactions were carried out in a closed Teflon vessel which was placed, for irradiation, at the center of the oven. IR spectra were recorded with Perkin-Elmer 1430 spectrometer ${ }^{1} \mathrm{H}$ NMR spectra were recorded on Jeol spectrometer (500 MHz). Chemical shifts $(\delta)$ are given in ppm relative to the signal for TMS as internal standard. Elemental analyses were performed in the unit of Microanalyses at Faculty of Science, Cairo University.

3-Chloro-2-hydrazinocarbonylbenzo[b]thiophene (2). A mixture of acid chloride 1 (1 mmol), dry chloroform $(5 \mathrm{ml})$ and hydrazine hydrate $(1 \mathrm{mmol})$ in a closed Teflon vessel was irradiated with MW for $1.5 \mathrm{~min}$. The product was recrystallized from ethanol as yellow needles, mp 169$170{ }^{\circ} \mathrm{C}$ (lit. mp 169-171) ${ }^{31}$.

2-Carbonyl-potassium-dithiocarbazinate 3-chlorobenzo[b]thiophene (3). Method A. Carbon disulfide $(15 \mathrm{mmol})$ was added dropwise to a solution of $2(10 \mathrm{mmol})$ in absolute ethanol $(50 \mathrm{ml})$ containing potassium hydroxide $(15 \mathrm{mmol})$ at $0{ }^{\circ} \mathrm{C}$. The reaction was stirred at room temperature for $16 \mathrm{~h}$, and then cooled and diluted with diethyl ether. The precipitate was filtered, washed with diethyl ether and dried. The potassium dithiocarbazinate $\mathbf{3}$ was obtained in nearly quantitative yield and used without further purification as it was moisture sensitive.

Method B. A mixture of compound $2(1 \mathrm{mmol}), \mathrm{KOH}(1.5 \mathrm{mmol})$ and ethanol $(5 \mathrm{ml})$ was treated with carbon disulphide $(1.5 \mathrm{mmol})$ at $0{ }^{\circ} \mathrm{C}$. The reaction mixture was placed in closed Teflon vessel and irradiated by MW for $4 \mathrm{~min}$. The reaction mixture was processed as described above (Table 1).

4-Amino-5-(3-chlorobenzo[b]thien-2-yl)-3-mercapto-1,2,4-triazole (4). Method A. Hydrazine hydrate $(95 \%, 20 \mathrm{mmol})$ was added to a suspension of the potassium salt $3(10 \mathrm{mmol})$ in water $(10 \mathrm{ml})$ and the mixture was refluxed with stirring for $4 \mathrm{~h}$. After cooling, it was diluted with water then acidified with aqueous hydrochloric acid. The precipitate was filtered, washed with water and recrystallized from ethanol to give yellow needles, mp 198-199 ${ }^{\circ} \mathrm{C}$; IR: $1549(\mathrm{C}=\mathrm{C})$, $1610(\mathrm{C}=\mathrm{N}), 3063\left(\mathrm{NH}_{2}\right) \mathrm{cm}^{-1} ;{ }^{1} \mathrm{H}$ NMR $\left(\mathrm{DMSO}-d_{6}\right) \delta 5.84\left(\mathrm{~s}, 2 \mathrm{H}, \mathrm{D}_{2} \mathrm{O}\right.$ exchangeable, $\left.\mathrm{NH}_{2}\right)$, 7.53-7.57 (m, 2H, H-5, H-6, benzothiophene), 7.90 (dd, 1H, H-4, J=3.1 Hz, J = 8.4 Hz), 8.13 $(\mathrm{dd}, 1 \mathrm{H}, \mathrm{H}-7, J=3.1, J=8.4 \mathrm{~Hz}), 14.20\left(\mathrm{~s}, 1 \mathrm{H}, \mathrm{D}_{2} \mathrm{O}\right.$ exchangeable, $\left.\mathrm{SH}\right)$. Anal. Calcd for $\mathrm{C}_{10} \mathrm{H}_{7} \mathrm{ClN}_{4} \mathrm{~S}_{2}$ : C, 42.47; H, 2.50; N, 19.81. Found: C, 42.33; H, 2.64; N, 20.05.

Method B. A mixture of potassium salt 3 (1 mmol), water $(1 \mathrm{ml})$ and hydrazine hydrate $(95 \%, 1$ mmol) in a closed Teflon vessel was irradiated by MW for $2 \mathrm{~min}$. The reaction mixture was processed as described above (Table 1).

5-(3-Chlorobenzo[b]thien-2-yl)-4-formylamino-3-mercapto-1,2,4-triazole(5). Method A. A solution of compound $4(10 \mathrm{mmol})$ in formic acid $(30 \mathrm{ml})$ was refluxed for $20 \mathrm{~h}$. Excess of solvent was removed under reduced pressure. The product was washed with water, dried and recrystallized from ethanol to give pale yellow crystals, mp 242-243 ${ }^{\circ} \mathrm{C}$; IR: $1599(\mathrm{C}=\mathrm{C}), 1677$ 
$(\mathrm{C}=\mathrm{N}), 1690(\mathrm{C}=\mathrm{O}), 3013\left(\mathrm{C}-\mathrm{H} \text { Ar), } 3276(\mathrm{NH}) \mathrm{cm}^{-1} ;{ }^{1} \mathrm{H} \text { NMR (DMSO-d }\right)_{6} \delta$ 7.58-7.60 (m, 2H, H-5, H-6 benzothiophene), 7.89-7.93 (m, 1H, H-4 benzothiophene), 8.14-8.17 (m, 0.86H, H7(A) benzothiophene), 8.17-8.19 (m, 0.14H, H-7(B) benzothiophene), 8.33 (s, 0.14H, HCO(B)), $8.38(\mathrm{~s}, 0.86 \mathrm{H}, \mathrm{HCO}(\mathrm{A})), 11.09\left(\mathrm{~s}, 0.14 \mathrm{H}, \mathrm{D}_{2} \mathrm{O}\right.$ exchangeable, $\left.\mathrm{NH}(\mathrm{B})\right), 11.79\left(\mathrm{~s}, 0.86 \mathrm{H}, \mathrm{D}_{2} \mathrm{O}\right.$ exchangeable, $\mathrm{NH}(\mathrm{A})), 14.58\left(\mathrm{~s}, 1 \mathrm{H}, \mathrm{D}_{2} \mathrm{O}\right.$ exchangeable, $\left.\mathrm{SH}\right)$. Anal. Calcd for $\mathrm{C}_{11} \mathrm{H}_{7} \mathrm{ClN}_{4} \mathrm{OS}_{2}$ : C, 42.51; H, 2.27; N, 18.03. Found: C, 42.78; H, 2.15; N, 17.89 .

Method B. A solution of compound $4(1 \mathrm{mmol})$ in formic acid $(3 \mathrm{ml})$ in a closed Teflon vessel was irradiated by MW for $3 \mathrm{~min}$. The reaction mixture was processed as described above (Table 1).

\section{3-(3-Chlorobenzo[b]thien-2-yl)-6-methyl-1,2,4-triazolo[3,4-b][1,3,4]thiadiazole (8)}

Method A. A solution of compound $4(10 \mathrm{mmol})$ in acetic anhydride $(50 \mathrm{ml})$ was heated under reflux for $18 \mathrm{~h}$. The reaction mixture was then poured onto crushed ice. The product was filtered out and recrystallized from ethanol to give yellow crystals, mp $212{ }^{\circ} \mathrm{C}$; IR: $1556(\mathrm{C}=\mathrm{C}), 1642$ $(\mathrm{C}=\mathrm{N}), 3060(\mathrm{C}-\mathrm{H} \mathrm{Ar}) \mathrm{cm}^{-1}$; ${ }^{1} \mathrm{H}$ NMR $\left(\mathrm{CDCl}_{3}\right) \delta 2.78\left(\mathrm{~s}, 3 \mathrm{H}, \mathrm{CH}_{3}\right), 7.47-7.52$ (m. 2H, H-5, H6), $7.86(\mathrm{~d}, 1 \mathrm{H}, \mathrm{H}-4, J=6.9 \mathrm{~Hz}), 7.98(\mathrm{~d}, 1 \mathrm{H}, \mathrm{H}-7, J=7.7 \mathrm{~Hz})$. Anal. Calcd for $\mathrm{C}_{12} \mathrm{H}_{7} \mathrm{ClN}_{4} \mathrm{~S}_{2}$ : C, 46.98; H, 2.30; N, 18.26. Found: C, 47.15; H, 2.46; N, 18.48 .

Method B. A solution of compound 4 (1 mmol) in acetic anhydride $(5 \mathrm{ml})$ in a closed Teflon vessel was irradiated by MW for $3 \mathrm{~min}$. The reaction mixture was processed as described above (Table 1).

\section{3-(3-Chlorobenzo[b]thien-2-yl)-1,2,4-triazolo[3,4-b][1,3,4] thiadiazol-6(5H)thione (9)}

Method A. A mixture of $4(10 \mathrm{mmol})$ and thiourea $(12 \mathrm{mmol})$ was fused at $180-190{ }^{\circ} \mathrm{C}$ for $3 \mathrm{~h}$, then allowed to cool and washed with water. The solid was filtered and recrystallized from ethanol to give yellow plates, mp 248-250 ${ }^{\circ} \mathrm{C}$; IR: $1521(\mathrm{C}=\mathrm{C}), 1586(\mathrm{C}=\mathrm{N}), 3057(\mathrm{C}-\mathrm{H} \mathrm{Ar}) \mathrm{cm}^{-}$ ${ }^{1} ;{ }^{1} \mathrm{H}$ NMR (DMSO-d $\left.)\right) \delta$ 7.35-7.52 (m, 2H, H-5, H-6 benzothiophene), 7.80-8.02 (m, 2H, H-4, $\mathrm{H}-7), 9.40$ (s, $1 \mathrm{H}, \mathrm{D}_{2} \mathrm{O}$ exchangeable, $\mathrm{NH}$ ). Anal. Calcd for $\mathrm{C}_{11} \mathrm{H}_{5} \mathrm{ClN}_{4} \mathrm{~S}_{3}$ : C, 40.67; H, 1.55; N, 17.25. Found: C, 40.98; H, 1.73; N, 17.08 .

Method B. A mixture of $4(1 \mathrm{mmol})$ and carbon disulphide $(0.1 \mathrm{ml})$ in pyridine $(3 \mathrm{ml})$ in a closed Teflon vessel was irradiated by MW for $4 \mathrm{~min}$. The reaction mixture was processed as described above (Table 1).

Method C. A mixture of $4(10 \mathrm{mmol})$ and carbon disulphide $(1 \mathrm{ml})$ in pyridine $(25 \mathrm{ml})$ was refluxed for $8 \mathrm{~h}$, then left to cool and poured on ice-cold water. The solid obtained was filtered, washed with water, dried and recrystallized from ethanol to give yellow plates identical with the product obtained above.

\section{3-(3-Chlorobenzo[b]thien-2-yl)-1,2,4-triazolo[3,4-b][1,3,4]thiadiazol-6(5H)one (11)}

A mixture of $4(10 \mathrm{mmol})$ and urea $(12 \mathrm{mmol})$ was fused at $180-190{ }^{\circ} \mathrm{C}$ for $3 \mathrm{~h}$, then allowed to cool and diluted with water. The solid was filtered off and recrystallized from chloroform/methanol to give yellow plates, mp 239-240 ${ }^{\circ} \mathrm{C}$; IR: $1580(\mathrm{C}=\mathrm{C}), 1697(\mathrm{C}=\mathrm{O}), 3048$ (C-H Ar), 3205 (NH) cm ${ }^{-1}$; ${ }^{1} \mathrm{H}$ NMR (DMSO-d $\left.d_{6}\right) \delta$ 7.51-7.56 (m, 2H, H-5, H-6 benzothiophene), $7.86(\mathrm{~d}, 1 \mathrm{H}, \mathrm{H}-4, J=6.9 \mathrm{~Hz}), 8.07$ (d, 1H, H-7, $J=6.9), 11.14$ (s, 1H, $\mathrm{D}_{2} \mathrm{O}$ exchangeable, NH). Anal. Calcd for $\mathrm{C}_{11} \mathrm{H}_{5} \mathrm{ClN}_{4} \mathrm{OS}_{2}$ : C, 42.79; H, 1.62; N, 18.15. Found: C, 43.10; H, 1.90; N, 18.42. 


\section{3-(3-Chlorobenzo[b]thien-2-yl)-5H-1,2,4-triazolo[3,4-b][1,3,4]thiadiazino[5,7-b]qui- noxaline (12)}

Method A. To a solution of compound $4(10 \mathrm{mmol})$ in DMF $(25 \mathrm{ml})$ and $\mathrm{K}_{2} \mathrm{CO}_{3}(10 \mathrm{mmol})$, the 2,3-dichloroquinoxaline $(10 \mathrm{mmol})$ was added with stirring. The reaction mixture was heated under reflux for $2 \mathrm{~h}$, then left to cool and poured on ice-cold water. The solid was filtered, washed with water, dried and recrystallized from ethanol to give orange needles, $\mathrm{mp}>300{ }^{\circ} \mathrm{C}$; IR: $1577(\mathrm{C}=\mathrm{C}), 1625(\mathrm{C}=\mathrm{N}), 3055(\mathrm{C}-\mathrm{H} \mathrm{Ar}), 3341(\mathrm{NH}) \mathrm{cm}^{-1} ;{ }^{1} \mathrm{H}$ NMR (DMSO-d $) \delta$ 7.027.07 (m, 2H, H-2, H-3 quinoxaline), 7.25-7.35 (m, 2H, H-1, H-4, quinoxaline), 7.56-7.60 (m, 2H, H-5, H-6 benzothiophene), 7.91 (dd, 1H, H-4, $J=2.3, J=8.4 \mathrm{~Hz}), 8.10$ (dd, 1H, H-7, $J=3.1, J$ $=8.4 \mathrm{~Hz}), 11.85\left(\mathrm{~s}, 1 \mathrm{H}, \mathrm{D}_{2} \mathrm{O}\right.$ exchangeable, $\left.\mathrm{NH}\right)$. Anal. Calcd for $\mathrm{C}_{18} \mathrm{H}_{9} \mathrm{ClN}_{6} \mathrm{~S}_{2}: \mathrm{C}, 52.87 ; \mathrm{H}$, 2.22; N, 20.55. Found: C, 52.63; H, 2.31; N, 20.31.

Method B. A mixture of compound 4 (1 mmol), $\mathrm{K}_{2} \mathrm{CO}_{3}(1 \mathrm{mmol})$ and the 2,3dichloroquinoxaline $(1 \mathrm{mmol})$ in DMF $(3 \mathrm{ml})$ in a closed Teflon vessel was irradiated by MW for $1.5 \mathrm{~min}$. The reaction mixture was processed as described above (Table 1).

\section{5-(3-Chlorobenzo[b]thien-2-yl)-4H-1,2,4-triazole (14).}

Method A. A solution of compound $4(10 \mathrm{mmol})$ in hydrochloric acid $(50 \mathrm{ml})$ was cooled to 0 ${ }^{\circ} \mathrm{C}$ and a cold solution of $\mathrm{NaNO}_{2}(10 \mathrm{mmol})$ in water $(10 \mathrm{ml})$ was gradually added. The reaction mixture was kept at $0-5{ }^{\circ} \mathrm{C}$ with stirring for $2 \mathrm{~h}$, left overnight and neutralized with $\mathrm{NaOH}$. The solid was filtered, washed with water, dried and recrystallized from ethanol to give colorless plates, mp 178-179 ${ }^{\circ} \mathrm{C}$; IR: $1590(\mathrm{C}=\mathrm{C}), 1660(\mathrm{C}=\mathrm{N}), 3087\left(\mathrm{C}-\mathrm{H}\right.$ Ar), $3382(\mathrm{NH}) \mathrm{cm}^{-1}$; ${ }^{1} \mathrm{H}$ NMR (DMSO-d D $_{\text {) }} \delta$ 7.48-7.53 (m, 2H, H-5, H-6 benzothiophene), 7.83 (d, 1H, H-4, J = 6.9 Hz), 8.04 (d, 1H, H-7, J = 6.9), 8.69 (s, 1H, triazole-H), 13.94 (s, 1H, $\mathrm{D}_{2} \mathrm{O}$ exchangeable, $\left.\mathrm{NH}\right)$. Anal. Calcd for $\mathrm{C}_{10} \mathrm{H}_{6} \mathrm{ClN}_{3} \mathrm{~S}$ : C, 50.96; H, 2.57; N, 17.83. Found C, 51.22; H, 2.69; N, 18.02.

Method B. A mixture of compound $4(1 \mathrm{mmol})$ in $\mathrm{HCl}(5 \mathrm{ml})$ and water $(1 \mathrm{ml})$ was treated with $\mathrm{NaNO}_{2}(1 \mathrm{mmol})$ at $0{ }^{\circ} \mathrm{C}$. The reaction mixture was placed in a closed Teflon vessel and irradiated by MW for $2 \mathrm{~min}$. The reaction mixture was processed as described above to give the same product (Table 1).

Method C. A suspension of $4(10 \mathrm{mmol})$ in orthophosphoric acid $(20 \mathrm{ml})$ was treated with $\mathrm{NaNO}_{2}(1 \mathrm{mmol})$ at $0{ }^{\circ} \mathrm{C}$. The reaction mixture was kept at $0-5{ }^{\circ} \mathrm{C}$ with stirring for $2 \mathrm{~h}$, left overnight and neutralized with $\mathrm{NaOH}$. The solid was filtered, washed with water, dried and recrystallized from ethanol to give colorless plates identical with the product above. A similar product was also obtained by placing the reaction mixture in a closed Teflon vessel and irradiated by MW for $2 \mathrm{~min}$. The reaction mixture was processed as described above (Table 1).

\section{[4-Amino-5-(3-chlorobenzo[b]thien-2-yl)-1,2,4-triazol-3-yl]mercaptoacetic acid (15)}

Method A. A mixture of $4(10 \mathrm{mmol})$, chloroacetic acid $(10 \mathrm{mmol})$ and potassium hydroxide $(10$ mmol) in $\mathrm{H}_{2} \mathrm{O}(25 \mathrm{ml})$ was refluxed for $6 \mathrm{~h}$. The solution was cooled, filtered and acidified with diluted hydrochloric acid. The precipitate was filtered off and recrystallized from ethanol to give colorless needles, mp $207{ }^{\circ} \mathrm{C}$; IR: $1538(\mathrm{C}=\mathrm{C}), 1628(\mathrm{C}=\mathrm{N}), 1708(\mathrm{C}=\mathrm{O}), 3059(\mathrm{C}-\mathrm{H}$ Ar), 3272 $\left(\mathrm{NH}_{2}\right) \mathrm{cm}^{-1} ;{ }^{1} \mathrm{H}$ NMR (DMSO-d $\left.)_{6}\right) \delta .06\left(\mathrm{~s}, 2 \mathrm{H}, \mathrm{SCH}_{2}\right), 6.23\left(\mathrm{~s}, 2 \mathrm{H}, \mathrm{D}_{2} \mathrm{O}\right.$ exchangeable, $\mathrm{NH}_{2}$ ), 7.55-7.59 (m, 2H, H-5, H-6 benzothiophene), 7.91 (d, 1H, H-4, J=2.3, J=6.9 Hz), 8.14 (d, 1H, 
$\mathrm{H}-7, J=2.3, J=6.9 \mathrm{~Hz}), 12.38\left(\mathrm{~s}, 1 \mathrm{H}, \mathrm{D}_{2} \mathrm{O}\right.$ exchangeable, $\left.\mathrm{COOH}\right)$. Anal. for $\mathrm{C}_{12} \mathrm{H}_{9} \mathrm{ClN}_{4} \mathrm{O}_{2} \mathrm{~S}_{2}$ : Calcd C, 42.29; H, 2.66; N, 16.44. Found: C, 42.45; H, 2.52; N, 16.57.

Method B. A mixture of compound 4 (1 mmol), chloroacetic acid (1 mmol), potassium hydroxide $(1 \mathrm{mmol})$ in $\mathrm{H}_{2} \mathrm{O}(5 \mathrm{ml})$ in a closed Teflon vessel was irradiated by $\mathrm{MW}$ for $2.5 \mathrm{~min}$. The reaction mixture was processed as described above (Table 1).

\section{3-(3-Chlorobenzo[b]thien-2-yl)-5H-1,2,4-triazolo[3,4-b][1,3,4]thiadiazin-6(7H)one (16).}

Method A. A mixture of 4 (10 $\mathrm{mmol})$, ethyl chloroacetate $(10 \mathrm{mmol})$ and potassium hydroxide $(10 \mathrm{mmol})$ in water $(25 \mathrm{ml})$ was refluxed for $8 \mathrm{~h}$. The solution was cooled, filtered and acidified with dil $\mathrm{HCl}$. The product was filtered off and recrystallized from ethanol to give colorless needles, mp $163{ }^{\circ} \mathrm{C}$; IR: $1544(\mathrm{C}=\mathrm{C}), 1620(\mathrm{C}=\mathrm{N}), 1670(\mathrm{C}=\mathrm{O}), 3045(\mathrm{C}-\mathrm{H} \mathrm{Ar}), 3210(\mathrm{NH}) \mathrm{cm}^{-1}$; ${ }^{1} \mathrm{H}$ NMR (DMSO-d $)_{6} \delta 3.98$ (s, 2H, SCH ), 7.54-7.59 (m, 2H, H-5, H-6 benzothiophene), 7.91 $(\mathrm{d}, 1 \mathrm{H}, \mathrm{H}-4, J=6.9 \mathrm{~Hz}), 8.13$ (d, 1H, H-7, $J=6.9 \mathrm{~Hz}), 8.90\left(\mathrm{~s}, 1 \mathrm{H}, \mathrm{D}_{2} \mathrm{O}\right.$ exchangeable, CONH). Anal. Calcd for $\mathrm{C}_{12} \mathrm{H}_{7} \mathrm{ClN}_{4} \mathrm{OS}_{2}$ : C, 44.65; H, 2.19; N, 17.36. Found: C, 44.87; H, 2.42; N, 17.11. Method B. A mixture of 4 (1 mmol), ethyl chloroacetate $(1 \mathrm{mmol})$ and potassium hydroxide (1 $\mathrm{mmol})$ in water $(5 \mathrm{ml})$ in a closed Teflon vessel was irradiated by MW for $3 \mathrm{~min}$. The reaction mixture was processed as described above (Table 1).

\section{Ethyl-[5-(3-chlorobenzo[b]thien-2-yl)-4-amino-1,2,4-triazol-3-yl]mercaptoacetate (17).}

Method A. A mixture of $4(10 \mathrm{mmol})$, ethyl chloroacetate $(10 \mathrm{mmol})$ and triethylamine (10 $\mathrm{mmol})$ in ethanol $(25 \mathrm{ml})$ was refluxed for $2 \mathrm{~h}$. Ethanol was removed under reduced pressure, and the product was recrystallized from ethanol to give yellow crystals, mp: $116-117^{\circ} \mathrm{C}$; IR: $1588(\mathrm{C}=\mathrm{C}), 1636(\mathrm{C}=\mathrm{N}), 1724(\mathrm{C}=\mathrm{O}), 3060\left(\mathrm{C}-\mathrm{H}\right.$ Ar), $3311\left(\mathrm{NH}_{2}\right) \mathrm{cm}^{-1} ;{ }^{1} \mathrm{H}$ NMR $\left(\mathrm{CDCl}_{3}\right) \delta$ $1.27\left(\mathrm{t}, 3 \mathrm{H}, \mathrm{CH}_{2} \underline{\mathrm{CH}}_{3}, J=7.7 \mathrm{~Hz}\right), 3.96\left(\mathrm{~s}, 2 \mathrm{H}, \mathrm{SCH}_{2}\right), 4.20\left(\mathrm{q}, 2 \mathrm{H}, \underline{\mathrm{CH}}_{2} \mathrm{CH}_{3}\right), 5.24\left(\mathrm{~s}, 2 \mathrm{H}, \mathrm{D}_{2} \mathrm{O}\right.$ exchangeable, $\mathrm{NH}_{2}$ ), 7.45-7.50 (m, 2H, H-5, H-6, benzothiophene), 7.82 (dd, 1H, H-4, J = 3.1 $\mathrm{Hz}, J=6.9 \mathrm{~Hz}), 7.90(\mathrm{dd}, 1 \mathrm{H}, \mathrm{H}-7, J=3.1 \mathrm{~Hz}, J=7.7 \mathrm{~Hz})$. Anal. Calcd for $\mathrm{C}_{14} \mathrm{H}_{13} \mathrm{ClN}_{4} \mathrm{O}_{2} \mathrm{~S}_{2}$ : C, 45.59; H, 3.55; N, 15.19. Found: C, 45.80; H, 3.47; N, 15.32.

Method B. A mixture of 4 (1 mmol), ethyl chloroacetate $(1 \mathrm{mmol})$ and triethylamine $(1 \mathrm{mmol})$ in ethanol $(5 \mathrm{ml})$ in a closed Teflon vessel was irradiated by MW for $1.5 \mathrm{~min}$. The reaction mixture was processed as described above (Table 1).

\section{Reaction of 4 with ethyl chloroacetate catalyzed by sodium ethoxide.}

Method A. A mixture of $4(10 \mathrm{mmol})$, ethyl chloroacetate $(10 \mathrm{mmol})$ in an ethanolic solution of sodium ethoxide prepared from sodium metal $(0.23 \mathrm{~g})$ in ethanol $(150 \mathrm{ml})$ was refluxed for $10 \mathrm{~h}$. The solution was concentrated, cooled, diluted with water and left overnight. The precipitate was filtered off and fractionated by column chromatography eluted with Hexane:EtOAc (30:1). The first fraction gives yellow crystals of 3-(3-chlorobenzo[b]thien-2-yl)-6-ethoxy-7H-1,2,4-

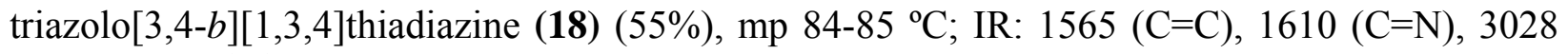
$\left(\mathrm{C}-\mathrm{H} \text { Ar) } \mathrm{cm}^{-1} ;{ }^{1} \mathrm{H} \text { NMR (DMSO-d }\right)_{6} \delta 1.16\left(\mathrm{t}, 2 \mathrm{H}, \mathrm{CH}_{2} \underline{\mathrm{CH}}_{3}, J=7.7 \mathrm{~Hz}\right), 4.15\left(\mathrm{q}, 2 \mathrm{H}, \underline{\mathrm{CH}_{2}} \mathrm{CH}_{3}\right)$, 4.27 (s, 2H, $\mathrm{SCH}_{2}$ ), 7.57-7.61 (m, 2H, H-5, H-6 benzothiophene), 7.93 (dd, 1H, H-4, J=3.1 Hz, $J=7.7 \mathrm{~Hz}), 8.14\left(\mathrm{dd}, 1 \mathrm{H}, \mathrm{H}-7, J=3.1 \mathrm{~Hz}, J=7.7 \mathrm{~Hz}\right.$ ). Anal. Calcd for $\mathrm{C}_{14} \mathrm{H}_{11} \mathrm{ClN}_{4} \mathrm{OS}_{2}$ : C, 47.93; H, 3.16; N, 15.97. Found: C, 48.15; H, 3.29; N, 15.81\%

The second fraction gives colorless crystals of $16(32 \%)$. 
Method B. A similar mixture of $4(0.3 \mathrm{mmol})$, ethyl chloroacetate $(0.3 \mathrm{mmol})$ in an ethanolic solution of sodium ethoxide $(5 \mathrm{ml})$ in a closed Teflon vessel was irradiated by MW for $4 \mathrm{~min}$. The reaction mixture was processed as described above to give $\mathbf{1 6}$ and $\mathbf{1 8}$ (Table 1).

\section{[4-Amino-5-(3-chlorobenzo[b]thien-2-yl-1,2,4-triazol-3-yl)]mercaptoacetic acid hydrazide} (19).

Method A. A mixture of $14(10 \mathrm{mmol})$, hydrazine hydrate $(10 \mathrm{mmol})$ in ethanol $(25 \mathrm{ml})$ was refluxed for $6 \mathrm{~h}$. Ethanol was removed under reduced pressure, and the product was recrystallized from ethanol to give pale yellow plates, mp 190-191 ${ }^{\circ} \mathrm{C}$; IR: $1566(\mathrm{C}=\mathrm{C}), 1638$ $(\mathrm{C}=\mathrm{N}), 1677(\mathrm{C}=\mathrm{O}), 3077\left(\mathrm{C}-\mathrm{H}\right.$ Ar), 3210, $3290\left(\mathrm{NH}, \mathrm{NH}_{2}\right) \mathrm{cm}^{-1} ;{ }^{1} \mathrm{H}$ NMR (DMSO-d 6$) \delta 3.87$ $\left(\mathrm{s}, 2 \mathrm{H}, \mathrm{SCH}_{2}\right), 4.34$ (s, 2H, $\mathrm{D}_{2} \mathrm{O}$ exchangeable, $\left.\mathrm{NH} \underline{N H}_{2}\right), 6.22\left(\mathrm{~s}, 2 \mathrm{H}, \mathrm{D}_{2} \mathrm{O}\right.$ exchangeable, $\left.\mathrm{NH}_{2}\right)$, 7.54-7.58 (m, 2H, H-5, H-6 benzothiophene), 7.90 (d, 1H, H-4, J = 6.9 Hz), 8.13 (d, 1H, H-7, J= 6.9), 9.35 (s, $1 \mathrm{H}, \mathrm{D}_{2} \mathrm{O}$ exchangeable, $\underline{\mathrm{NH}} \mathrm{NH}_{2}$ ). Anal. Calcd for $\mathrm{C}_{12} \mathrm{H}_{11} \mathrm{ClN}_{6} \mathrm{OS}_{2}$ : C, 40.62; $\mathrm{H}$, 3.12; N, 23.68. Found: C, 40.89; H, 2.97; N, 23.52\%.

Method B. A mixture of 14 (1 mmol), hydrazine hydrate $(1 \mathrm{mmol})$ in ethanol $(5 \mathrm{ml})$ in a closed Teflon vessel was irradiated by MW for $2 \mathrm{~min}$. The reaction mixture was processed as described above (Table 1).

\section{3-(3-Chlorobenzo[b]thein-2-yl)-6-( $N, N$-dimethylamino)-1,2,4-triazolo[3,4-b][1,3,4]} thiadiazole (21).

Method A. A solution of compound $4(10 \mathrm{mmol})$ in DMF $(25 \mathrm{ml})$ was refluxed for $20 \mathrm{hr}$, then left to cool and poured on ice-cold water. The solid was filtered, washed with water, dried and recrystallized from ethanol to give pale yellow crystals, mp $230-232{ }^{\circ} \mathrm{C}$; IR: $1483(\mathrm{C}=\mathrm{C}), 1608$ $(\mathrm{C}=\mathrm{N}), 2920,2849\left(\mathrm{CH}_{3}\right) \mathrm{cm}^{-1} ;{ }^{1} \mathrm{H}$ NMR $\left(\mathrm{DMSO}-\mathrm{d}_{6}\right) \delta 1.18\left(\mathrm{~s}, 6 \mathrm{H}, \mathrm{N}\left(\mathrm{CH}_{3}\right)_{2}\right), 7.51-7.56(\mathrm{~m}, 2 \mathrm{H}$, H-5, H-6 benzothiophene), 7.87 (d, 1H, H-4, J=6.9 Hz), 8.07 (d, 1H, H-7, J=6.9 Hz). Anal. Calcd for $\mathrm{C}_{13} \mathrm{H}_{10} \mathrm{ClN}_{5} \mathrm{OS}_{2}$ (335.84): C, 46.49; H, 3.00; N, 20.85. Found: C, 46.73; H, 2.79; N, 21.07 .

Method B. A solution of 4 (1 mmol) in DMF $(5 \mathrm{ml})$ was irradiated by MW in a closed Teflon vessel for $6 \mathrm{~min}$. The reaction mixture was processed as described above (Table 1).

\section{References}

1. Griffin, D. A.; Mannion, S. K. Eur. Pat. Appl. Ep 1986, 199,474; Chem. Abstr. 1987, 106, 98120u.

2. Hussain, M. I.; Amir, M. J. Indian Chem. Soc. 1986, 63, 317 .

3. Chiu, S. -H. L.; Huskey, S. -E. W. Drug Metabol. Dispos. 1998 26, 838.

4. H. Emilsson, H. Salender, J. Gaarder, Eur. J. Med. Chem. Chim. Ther. 1985, 21, 333.

5. Demirbas, N.; Ugurluoglu Demirbas, A. Bioorg. Med. Chem. 2002, 10, 3717.

6. Turan-Zitouni, G.; Kaplancikli, Z. A.; Erol, K.; Kilic, F. S. IL Farmaco 1999, 54, 218.

7. Holla, B. S.; Kalluraya, B. Indian J. Chem. Sect. B 1988, 27, 683. 
8. Prasad, A. R.; Ramalingam, T.; Rao, A. B.; Diwan, P. W.; Sattur, P. B. Eur. J. Med. Chem. 1989, 24, 199.

9. El-Dawy, M. A., Omar, A. M. M. E.; AbM. Ismail, Hazzaa, A. A. B. J. Pharm. Sci. 1983, $72,45$.

10. Giri, S.; H. Singh, Yadav, L. D. S.; Khare, R. K. J. Indian Chem. Soc. 1978, 55, 168.

11. Mody, M. K.; Prasad, A. R.; Ramalingham, T.; Suttur, P. B. J. Indian Chem. Soc. 1982, 59, 769.

12. Connor, D. T.; Cetenko, W. A.; Mullican, M. D.; Sorenson, R. J.; Unangst, P. C.; Weikert, R. J.; Adolphson, R. L.; Kennedy, J. A.; Thueson, D. O.; Wright, C. D.; Conroy, M. C. J. Med. Chem. 1992, 35, 958.

13. Joachim, G.; Werner, M.; Albrecht, W. Ger. Offen. 1973, 2,223,391; Chem. Abstr. 1974, 80, $59857 \mathrm{q}$.

14. Descamps, M. ; Etienne, V. Ger. Offen. 1974, 2,328,060; Chem. Abstr. 1974, 80, 59856p.

15. Graham, S. L.; Shepard, K. L.; Anderson, P. S.; Baldwin, J. J.; Best, D. B.; Christy, M. E.; Freedman, M. B.; Gautheron, P.; Habecker, C. N.; Hoffman, J. M.; Lyle, P. A.; Michelson, S. R.; Ponticello, G. S.; Robb, C. M.; Schwam, H.; Smith, A. M.; Smith, R. L.; Sondey, J. M.; Strohmaier, K. M.; Sugrue, M. F.; Varga, S. L. J. Med. Chem. 1989, 32, 2548.

16. (a) Jones, C. D.; Jevnikar, M. G.; Pike, A. J.; Peters, M. K.; Black, L. J.; Thompson, A. R.; Falcone, J. F.; Clements, J. A. J. Med. Chem. 1984, 27, 1057; (b) Jordan, V. C. J. Med. Chem. 2003, 46, 883; (c) Jordan, V. C. J. Med. Chem. 2003, 46, 1081.

17. Abdel Rahman, A.; El Ashry, E. S. H. Synlett 2002, 2043.

18. Abdel-Hamid, H.; Ramadan, E.; Hagar, M.; El Ashry, E. S. H. Synth. Commun. 2004, 377.

19. El Ashry, E. S. H.; Ramadan, E.; Abdel-Hamid, H.; Hagar, M. Lett. Org. Chem. 2005, 2, 415.

20. El Ashry, E. S. H.; Ramadan, E.; Abdel-Hamid, H.; Hagar, M. Synth. Commun. 2005, 35, 2243.

21. El Ashry, E. S. H.; Ramadan, E.; Abdel-Hamid, H.; Hagar, M. J. Chem. Res. 2005229.

22. El Ashry, E. S. H.; Ramadan, E.; Abdel-Hamid, H.; Hagar, M. Synlett 2004, 723.

23. El Ashry, E. S. H.; Awad, L. F.; Abdel-Hamid, H.; Atta, I. A. J. Carbohydr. Chem. 2005, 24, 745 .

24. El Ashry, E. S. H.; Awad, L. F.; Abdel Hamid, H.; Atta, A. I. Nucleotides Nucleosides and Nucleic Acids 2006, 25, 325.

25. El Ashry, E. S. H.; Awad, L. F.; Abdel-Hamid, H.; Atta, I. A. Int. Soc. For Nucleosides, Nucleotides\&Nucleic acids XVIInt. Round Table, Minneaoplis, Minnesota, USA, (2004) PS. Nucleosides Nucleotides Nucleic acids 2005, 24, 427.

26. El Ashry, E. S. H.; Rashed, N.; Awad, L. F.; Ramadan, E.; Abdel-Maggeed, S. M.; Rezki, N. Arkivoc 2007, in press.

27. El Ashry, E. S. H.; Kassem, A. A.; Abdel-Hamid, H.; Louis, F. F.; Khattab, Sh. A. N.; Aouad, M. R. J. Heterocycl. Chem. 2006, in press. 
28. 28. Tierney,J. P.; Lidström, P. Microwave Assisted Organic Synthesis, Blackwell, Oxford 2005.

29. Hamelin, J.; Bazureau, J. P.; Texier-Boullet, F. Microwave in Organic Synthesis, ed, by A. Loupy, Wiley-VCH 2002, 253.

30. (a) El Ashry, E. S. H.; Ramadan, E.; Kassem, A. A.; Hagar, M. Adv. Heterocycl. Chem. 2005, 88, 1; (b) El Ashry, E. S. H.; Kassem, A. A.; Ramadan, E. Adv. Heterocycl. Chem. 2006, 90, 1; (c) El Ashry, E. S. H.; Kassem, A. A. ARKIVOC 2006, ix, 1.

31. Pakray, S.; Castle, R. N. J. Heterocycl. Chem. 1986, 23, 1621.

32. Ghorab, M. M.; El-Sharief, A. M. Sh.; Ammar, Y. A.; Mohamed, Sh. I. Il Farmaco 2000, $55,354$.

33. Wang, Z. H.; Shi, H. Shi. J. Heterocycl. Chem. 2001, 38, 355.

34. Mohan, J.; Kumar, V.; Indian J. Chem., Sect. B 1998, 37, 183.

35. Bano, Q.; Tiwari, N.; Giri Nizamuddin, S. Indian J. Chem., Sect. B 1992, 31, 714.

36. Awad, L. F.; El Ashry, E. S. H. Carbohydr. Res. 1998, 312, 9.

37. Shivarama Holla,B.; Narayana Poojary, K.; Kalluraya, B. Il Farmaco 1996, 51, 793.

38. Kidwai, M.; Goel, Y.; Kumar, P.; Kumar, K. Indian J. Chem., Sect. B 1997, 36, 782. 